\title{
PENGARUH PENERAPAN SISTEM INFORMASI AKUNTANSI TERHADAP KUALITAS LAPORAN KEUANGAN PADA BPKPD KOTA SURABAYA
}

\author{
Frista Chairina \\ Tineke Wehartaty* \\ Universitas Katolik Widya Mandala Surabaya, Jalan Dinoyo 42-44, Surabaya \\ tinekewm@yahoo.com
}

\author{
A R T I C L E I N F O \\ Article history: \\ Received August 14, 2018 \\ Revised October 19, 2018 \\ Accepted November 02, 2018
}

\section{Key words:}

Accounting Information System; Quality of Financial Statement; Financial and Tax Administration Board; e-accounting; Government Accounting

\begin{abstract}
A B S T R A C T
A good financial report is a financial statement containing and financial analysis. Improving the quality of financial statements in the municipal government sector in presenting financial statements in accordance with the Financial Accounting Standards (SAK) and Government Accounting Standards (SAP) that can not be issued from the efforts of the city government. Implementation of information systems is one effort to achieve the quality of financial statements, given the purpose of government financial reporting is for public accountability. This research was conducted at Surabaya City Financial and Tax Administration Board (BPKPD) implementing online finance software application (e-accounting) in year 2016. This study aims to analyze and prove the influence of application of accounting information system to the quality of financial statements at Financial and Tax Administration Board (BPKPD) of Surabaya. The results showed that the application of accounting information systems affect the quality of financial statements, meaning Utilization accounting information system helps BPKPD in providing quality financial information.
\end{abstract}

\begin{abstract}
A B S T R A K
Kualitas laporan keuangan yang baik merupakan laporan keuangan yang mengandung nilai manfaat dan memenuhi karakteristik kualitatif laporan keuangan. Peningkatan kualitas laporan keuangan pada sektor pemerintahan kota surabaya dalam menyajikan laporan keuangan yang sesuai dengan Standar Akuntansi Keuangan (SAK) dan Standar Akuntansi Pemerintah (SAP) yang berlaku tentunya tidak terlepas dari upaya pemerintah kota memanfaatkan penggunaan sistem informasi akuntansi. Penerapan sistem informasi akuntansi merupakan salah satu upaya untuk memenuhi kualitas laporan keuangan, mengingat tujuan dari pelaporan keuangan pemerintah adalah untuk akuntabilitas publik. Penelitian ini dilakukan di Badan Pengelola Keuangan dan Pajak Daerah (BPKPD) kota Surabaya yang menerapkan aplikasi keuangan berbasis online software (e-accounting) pada tahun 2016. Penelitian ini bertujuan untuk menganalisis dan membuktikan pengaruh penerapan sistem informasi akuntansi terhadap kualitas laporan keuangan pada Badan Pengelola Keuangan dan Pajak Daerah (BPKPD) kota Surabaya. Hasil penelitian menunjukkan bahwa penerapan sistem informasi akuntansi berpengaruh terhadap kualitas laporan keuangan, artinya Pemanfaatan sistem informasi akuntansi membantu $B P K P D$ dalam penyediaan informasi keuangan yang berkualitas.
\end{abstract}

\section{PENDAHULUAN}

Saat ini pengelolaan keuangan daerah sudah mengalami berbagai perubahan peraturan. Perubahan tersebut medukung suatu Pemerintah Daerah agar dapat mewujudkan good governance dan clean government. Keberhasilan dari suatu pembangunan daerah tidak terlepas dari aspek pengelolaan keuangan daerah yang baik dan taat aturan. Pengelolaan keuangan daerah merupakan suatu proses perencanaan, pelaporan, dan pertanggungjawaban keuangan daerah kepada Negara melalui penyusunan laporan anggaran pendapatan belanja daerah (APBD), neraca, laporan arus kas, dan cata$\tan$ atas laporan keuangan yang sesuai dengan Standar Akuntansi Pemerintahan (SAK). Pemerintah Daerah dituntut melakukan pengelolaan keuangan daerah yang tertib, transparan dan akuntabel. Laporan keuangan pemerintah yang 
dihasilkan akan melalui proses pemeriksaan Badan Pemeriksa Keuangan (BPK) untuk disampaikan kepada Dewan Perwakilan Daerah (DPRD). Oleh kerena itu, laporan keuangan daerah harus menyajikan informasi yang akurat, relevan dan tepat waktu.

Pengelolaan keuangan daerah kota Surabaya terus mengalami peningkatan, yang dapat dilihat dari prestasi yang diperoleh Pemerintah kota Surabaya dari Badan Pemeriksa Keuangan (BPK) dengan predikat opini wajar tanpa pengecualian (WTP) terkait Laporan Keuangan Pemerintah Daerah (LKPD) tingkat Provinsi Jatim dan pemerintah Kabupaten/Kota di Jawa Timur tahun anggaran 2016. Penghargaan terkait Laporan Keuangan Pemerintah Daerah (LKPD) tingkat Provinsi Jatim yang diperoleh pemerintah kota Surabaya sudah kali ke-7 sejak tahun anggaran 2011. Penerapan sistem elektronik yang transparan dan akuntabel untuk meningkatkan kualitas laporan keuangan menjadi alasan Pemkot Surabaya meraih predikat opini wajar tanpa pengecualian (WTP). Opini wajar tanpa pengecualian (WTP) menunjukkan bahwa pelaporan keuangan pemerintah kota Surabaya disajikan secara wajar sesuai dengan prinsip akuntansi yang berlaku umum.

Penelitian Prasisca, Kharlina, dan Yunita (2012) menjelaskan bahwa penerapan sistem informasi akuntansi membantu dalam penyajian informasi laporan keuangan yang sesuai dan bebas dari kesalahan saji. Penelitian Juwita (2013) membuktikan bahwa penerapan sistem informasi akuntansi pemerintahan yang baik membantu dalam meningkatkan kualitas laporan keuangan pada pemerintah kabupaten di Provinsi Jawa Barat. Hal tersebut juga didukung oleh penelitian Silviana dan Antoni (2014) yang menyatakan bahwa penerapan sistem informasi akuntansi berpengaruh terhadap kualitas laporan keuangan pemerintah kabupaten di Jawa Barat. Namun pada hasil penelitian Saputra (2015) membuktikan bahwa penerapan sistem informasi akuntansi tidak berpengaruh terhadap kualitas laporan keuangan. Hasil penelitian tersebut menunjukkan ketidakkonsistenan, sehingga perlu dilakukan penelitian lebih lanjut terkait pengaruh penerapan sistem inormasi akuntansi.

Pemerintah kota Surabaya telah mengintegrasikan sistem informasi akuntansi berupa aplikasi yang memudahkan dalam proses penyusunan laporan keungan. Prasisca, dkk. (2012) menyatakan bahwa sistem informasi akuntansi dibuat dan diarahkan untuk mendukung proses pembuatan laporan keuangan guna memenuhi kebutuhan pihak-pihak yang berkepentingan. Dalam menyajikan laporan keuangan pemerintah kota Surabaya telah menerapkan berbagai aplikasi keuangan khususnya e-accounting yang merupakan software akuntansi online yang mendukung proses penyusunan laporan keuangan pemerintah kota Surabaya yang mulai efektif diterapkan pada tahun 2016. Dengan menggunakan software akuntansi berbasis online memudahkan pihak internal dalam melakukan koreksi apabila terjadi kesalahan pada pencatatan, memudahkan proses pengendalian serta pembuatan laporan keuangan dengan lebih efektif dan efisien serta sebagai bentuk transparansi dan pertanggungjawaban laporan keuangan pemerintah yang telah diterbitkan pihak eksternal dapat diakses dengan mudah pada website pemerintah kota Surabaya.

Laporan keuangan daerah merupakan suatu bentuk pertanggungjawaban terhadap penggunaan dana APBD. Sesuai dengan Peraturan Pemerintah No. 71 Tahun 2010 mengenai Standar Akuntansi Pemerintahan (SAP) terkait karakteristik kualitatif laporan keuangan adalah ukuran-ukuran normatif yang perlu diwujudkan dalam informasi akuntansi sehingga dapat memenuhi tujuannya. Terdapat empat karakteristik yang merupakan prasyarat normatif yang diperlukan pemerintah agar dapat memenuhi kualitas laporan keuangan yang diharuskan yaitu relevan, andal, dapat dibandingkan, dan dapat dipahami. Kualitas informasi keuangan daerah didukung oleh pemanfaatan sistem informasi akuntansi.

Peningkatan kualitas laporan keuangan pada sektor pemerintahan kota Surabaya dalam menyajikan laporan keuangan yang sesuai dengan Standar Akuntansi Keuangan (SAK) dan Standar Akuntansi Pemerintah (SAP) yang berlaku tentunya tidak terlepas dari upaya pemerintah kota memanfaatkan penggunaan sistem informasi akuntansi. Penerapan sistem pengelolaan keuangan daerah ini tentunya dapat meningkatkan efektivitas dan efisiensi penggunaan anggaran dan juga mencegah terjadinya informasi keuangan yang fiktif melalui sistem informasi akuntansi yang transparan. Yang menjadi objek pada penelitian ini yaitu Badan Pengelola Keuangan dan Pajak Daerah di kota Surabaya. Badan Pengelola Keuangan dan Pajak Daerah merupakan instansi yang bertugas mengelola keuangan dan pendapatan pajak daerah kota Surabaya. Badan Pengelolaan Keuangan dan Pajak Daerah bertanggungjawab dalam pembuatan laporan keuangan tahunan yang disusun dari laporan keuangan 72 Satuan Kerja Perangkat Daerah (SKPD). Dengan menerapkan software e-accounting dinilai sangat membantu proses rekonsiliasi dan proses 
penyusunan laporan keuangan konsolidasian BPKPD yang sesuai dengan Peraturan Pemerintah.

Berdasarkan penjelasan yang telah diuraikan di atas, maka dapat dirumuskan permasalahan dalam penelitian ini adalah: apakah penerapan sistem informasi akuntansi berpengaruh terhadap kualitas pelaporan keuangan pemerintah pada Badan Pengelolaan Keuangan dan Pajak Daerah kota Surabaya? Penelitian ini diharapkan dapat membantu pemerintah kota Surabaya dalam mengelola pendapatan daerahnya dengan baik untuk mewujudkan good governance dan clean government.

\section{KAJIAN LITERATUR DAN PENGEMBANGAN HIPOTESIS}

Teori Kegunaan-Keputusan (Decision Usefullnes Theo$\underline{r y)}$

Teori kegunaan-keputusan informasi akuntansi diidentifikasi dalam disertasi Staubus pada tahun 1954 dengan judul An Accounting Concept of Revenue di University of Chicago Amerika Serikat. Teori kegunaan-keputusan informasi ini pertama kali dikenal dengan nama A Theory of Accounting to Investors. Tujuan dari Theory of Accounting to Investors adalah menyediakan informasi keuangan mengenai perusahaan untuk digunakan dalam membuat keputusan investasi (Staubus, 2000). Teori kegunaankeputusan informasi akuntansi dapat dilihat dari nilai manfaat informasi yang disajikan dalam laporan keuangan yang memenuhi standar dan komponen pelaporan sebagai dasar pengambilan keputusan (Silviana dan Antoni, 2014). Dapat disimpulkan bahwa konsep kegunaan-keputusan informasi mendasari pengambilan keputusan yang berasal dari informasi yang bermanfaat yaitu informasi yang sesuai dengan karakteristik dan memenuhi komponen pelaporan kauangan.

\section{Penerapan Sistem Informasi Akuntansi}

Penerapan sistem informasi akuntansi merupakan tahap implementasi sistem atau aplikasi bebrbasis keuangan yang mendukung proses pemenuhan informasi keuangan yang sesuai guna pengambilan keputusan oleh pihak yang berkepentingan. Sistem informasi akuntansi pemerintah dibuat sesuai dengan peraturan yang berlaku di Indonesia (Silviana dan Antoni, 2014). Sistem informasi akuntansi pemerintah dibuat dengan tujuan mendukung aktivitas rutin suatu instansi pemerintahan serta pemenuhan informasi keuangan sebagai bentuk pertanggungjawaban kepada Negara. Menurut Prasisca, dkk (2012) menyatakan bahwa dalam penerapannya sistem informasi akuntansi dibuat dan diarahkan untuk mendukung proses pembuatan laporan keuangan guna memenuhi kebutuhan informasi oleh pihak pihak yang berkepentingan sebagai dasar pengambilan keputusan. Dapat disimpulkan bahwa penerapan sistem informasi akuntansi pada instansi pemerintahan bertujuan untuk mendukung penyajian laporan keuangan yang sesuai dengan peraturan pemerintahan.

\section{Karakteristik Kualitatif Laporan Keuangan}

Laporan keuangan pemerintah dapat dikatakan telah memenuhi kualitas yang baik apabila telah memenuhi kriteria normatif pelaporan keuangan (Hasanah dan Fauzi, 2017:37). Teori tersebut didukung oleh pernyataan Juwita (2013) bahwa laporan keuangan yang berkualitas adalah laporan keuangan yang mencerminkan karakteristik pelaporan keuangan yaitu relevan, andal, dapat dibandingkan, dan mudah dipahami oleh pengguna laporan. Kurangnya pemanfaatan sistem informasi akuntansi dan pemahaman sumber daya mengenai standar akuntansi dapat menyebabkan laporan keuangan yang dihasilkan tidak memenuhi kualitas pelaporan (Setyowati, dkk., 2016).

Prinsip - prinsip penyusunan laporan keuangan dituangkan dalam Peraturan Pemerintah No. 71 Tahun 2010 mengenai Standar Akuntansi Pemerintah yang menjelaskan mengenai karakteristik kualitatif laporan keuangan merupakan kriteria normatif yang perlu diwujudkan dalam informasi akuntansi untuk mencapai tujuannya. Empat karakteristik yang merupakan prasyarat kriteria normatif yang harus ada untuk memenuhi kualitas laporan keuangan yaitu relevan, andal, dapat dibandingkan, dan dapat dipahami.

\section{Laporan Keuangan Pemerintah (Daerah)}

Akuntansi keuangan Daerah merupakan proses akuntansi yang terdiri dari proses identifikasi, pengukuran, pencatatan serta pelaporan setiap transaksi keuangan yang dilakukan oleh suatu organisasi pemerintahan (Halim, 2007). Laporan keuangan daerah dibuat untuk menyediakan kebutuhan informasi oleh pengguna yang berkepentingan sebagai pemerhati organisasi pemerintahan (daerah) meliputi masyarakat umum, badan pemeriksaan dan pengawasan, pihak pemberi dana, dan pemerintah pusat (Hasanah dan Fauzi, 2017).

Pelaporan keuangan pemerintah bertujuan untuk menyajikan dan menyediakan informasi yang bermanfaat dan dapat digunakan sebagai dasar pegambilan keputusan, sebagai suatu bentuk pertanggungjawaban kepada masyarakat, dan 
menilai kinerja maupun kondisi organisasi (Setyowati, Isthika, dan Pratiwi, 2016). Menurut Hasanah dan Fauzi (2017) komponen laporan keuangan pemerintah yang utama terdiri dari: Laporan Realisasi Anggaran (LRA), Neraca, Laporan Arus Kas, Catatan atas Laporan Keuangan, Laporan Kinerja Keuangan, dan Laporan Ekuitas.

Seiring perkembangan akuntansi pemerintahan di Indonesia, sistem pencatatan akuntansi pemerintahan kini mengalami perubahan dari kas basis menjadi akrual basis hal tersebut berlaku sejak tahun anggaran 2008 untuk pemerintah daerah maupun pusat. Akuntansi berbasis akrual merupakan pengakuan pencatatan transaksi pada saat terjadinya, sehingga dengan diterapkannya akuntansi berbasis akrual dapat menghasilkan informasi yang dapat diprtanggungjawabkan dan terbuka (Hasanah dan Fauzi, 2017). Sistem pencatatan basis akrual diimplementasikan pada pengakuan pendapatan, beban, aset, kewajiban, dan ekuitas (Yunita, 2015). Informasi yang disajikan lebih akurat bila sistem pencatatan akuntansi yang digunakan akrual basis karena pencatatan dilakukan setiap terjadinya transaksi.

Pengaruh Penerapan Sistem Informasi Akuntansi Terhadap Kualitas Laporan

Keuangan Teori kegunaan-keputusan merupakan konsep yang mendukung pemenuhan informasi keuangan yang bermanfaat guna pengambilan keputusan oleh pihak pemakai laporan. Penerapan sistem informasi akuntansi mendukung organisasi dalam membuat laporan eksternal, aktivitas rutin, pengambilan keputusan, perencanaan serta pengendalian (Rama dan Jones, 2008). Tujuan pelaporan keuangan daerah adalah untuk memenuhi kebutuhan pengguna laporan keuangan sebagai bentuk pertanggungjawaban kepada pemerintah pusat. Informasi yang disajikan dalam laporan keuangan harus sesuai dengan peraturan yang berlaku untuk mendukung pengguna laporan dalam memahami informasi yang disajikan. Menurut Peraturan Pemerintah No. 71 Tahun 2010 yang menjelaskan mengenai Standar Akuntansi Pemerintahan (SAP) terkait karakteristik kualitatif laporan keuangan merupakan ukuran normatif yang perlu diwujudkan dalam informasi akuntansi untuk memenuhi tujuannya. Terdapat empat karakteristik yang merupakan prasyarat ukuran normatif yang harus diwujudkan agar dapat memenuhi kualitas laporan yang diharuskan yaitu relevan, andal, dapat dibandingkan, dan dapat dipahami (Hasanah dan Fauzi, 2017). Salah satu upaya untuk memenuhi kualitas laporan keu- angan yang telah ditetapkan yaitu dengan pemanfaatan sistem informasi akuntansi. Menurut hasil penelitian Silviana dan Antoni (2014) menyatakan bahwa penggunaan sistem informasi akuntansi berpengaruh terhadap kualitas laporan keuangan. Prasisca, dkk (2012) dan Juwita (2013) juga menyatakan bahwa sistem informasi akuntansi berpengaruh positif dan signifikan terhadap kualitas laporan keuangan, dikarenakan sistem informasi akuntansi membantu dalam penyajian laporan keuangan yang sesuai dan bebas dari kesalahan saji. Berdasarkan penjelasan diatas maka hipotesis pada penelitian ini yaitu:

H1: Sistem Informasi Akuntansi Berpengaruh Signifikan Terhadap Kualitas Laporan Keuangan

\section{Model Analisis}

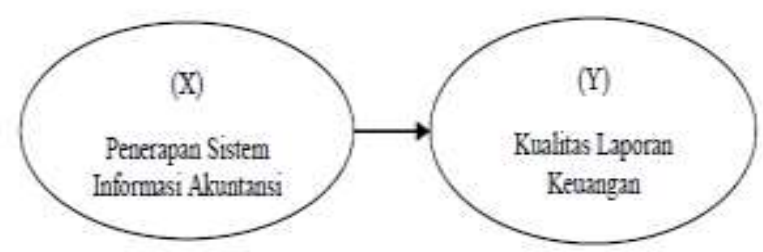

Gambar 1. Model Analisis

\section{METODE PENELITIAN}

\section{Populasi dan Sampel}

Populasi pada penelitian ini adalah karyawan pada Badan Pengelola Keuangan dan Pajak Daerah di kota Surabaya. Kriteria sampel (responden) pada penelitian ini yaitu karyawan pada Badan Pengelola Keuangan yang menggunakan aplikasi eaccounting dalam penyusunan dan penyajian laporan keuangan. Teknik pengambilan sampel yang digunakan pada penelitian ini adalah purposive sampling yaitu pengambilan sampel secara sengaja, dimana peneliti mempertimbangkan dan menentukan sendiri sampel yang akan diambil (tidak secara acak). Pengambilan data dilakukan dengan menyebarkan kuesioner pada tanggal 5 Juni 2018 sampai dengan 29 Juni 2018. Jumlah sampel minimal 5 kali dari jumlah indikator. Indikator pada penelitian ini berjumlah 20 sehingga sampel yang digunakan pada penelitian ini berjumlah 100. Berikut adalah distribusi kuesioner yang dibagikan kepada sampel (responden): 
Tabel 1. Distribusi Kuesioner

\begin{tabular}{|l|c|}
\hline \multicolumn{1}{|c|}{ Keterangan } & $\begin{array}{c}\text { Jumlah } \\
\text { Responden }\end{array}$ \\
\hline Kuesioner yang disebar & 100 \\
\hline $\begin{array}{l}\text { Kuesioner yang tidak } \\
\text { lengkap }\end{array}$ & 1 \\
\hline $\begin{array}{l}\text { Kuesioner yang tidak } \\
\text { memenuhi kriteria }\end{array}$ & 2 \\
\hline $\begin{array}{l}\text { Jumlah kuesioner yang } \\
\text { digunakan }\end{array}$ & 97 \\
\hline
\end{tabular}

\section{Definisi Operasional dan Pengukuran Variabel}

1. Penerapan Sistem Informasi Akuntansi

Penerapan sistem informasi akuntansi mendukung organisasi dalam membuat laporan eksternal, aktivitas rutin, pengambilan keputusan, perencanaan serta pengendalian (Rama dan Jones, 2008). Sistem informasi yang dikelola dengan baik mendukung pelaporan dan penyusunan laporan keuangan yang sesuai dengan peraturan yang berlaku (Saputra, 2015). Menurut Widjajanto (2001) sistem informasi akuntansi terdiri dari unsur masukan (input), proses, dan keluaran (output). Laporan keuangan merupakan keluaran yang berasal dari proses pengolahan data yang baik dengan tingkat 28 kesalahan yang rendah didukung oleh penerapan sistem informasi akuntansi dengan pengendalian dan arahan yang sesuai (Juwita, 2013). Indikator variabel penerapan sistem informasi akuntansi yang diangkat dari Prasisca, dkk (2012) yang terdiri dari prosedur pencatatan transaksi dilakukan berdasarkan standar pencatatan akuntansi dan pembuatan laporan keuangan secara periodik. Indikator variabel penerapan sistem informasi akuntansi berupa pernyataan kuesioner yang berisi 10 butir pertanyaan dan diukur dengan skala likert 1 yaitu sangat tidak setuju (STS) sampai dengan skala tertinggi yaitu 5 dengan alternatif jawaban sangat setuju (SS).

2. Kualitas Laporan Keuangan

Laporan keuangan dapat diakatakan berkualitas apabila laporan tersebut disajikan secara andal, relevan, dapat dibandingkan, dan dapat diapahami (Saputra, 2015). Pada Peraturan Pemerintah No. 71 Tahun 2010 menjelaskan mengenai karekteristik kualitatif laporan keuangan adalah kriteria normatif yang harus ada pada laporan keuangan dengan tujuan pemenuhan kualitas laporan keuangan. Berikut kareteristik kualitatif menurut Peraturan Pemerintah No. 71 Tahun 2010: Relevan, Andal, Dapat dibandingkan, dan dapat dipahami. Indikator variabel kualitas laporan keuangan yang diangkat dari penelitian Prasisca, dkk (2012) yaitu relevan, andal, dapat dipahami, dan dapat dibandingkan. Indikator variabel kualitas laporan keuangan berupa pernyataan kuesioner yang berisi 11 butir pertanyaan dan diukur dengan skala likert 1 yaitu sangat tidak setuju (STS) sampai dengan skala tertinggi yaitu 5 dengan alternatif jawaban sangat setuju (SS).

\section{$\underline{\text { Teknik Analisis Data }}$}

Dalam penelitian ini, regresi yang digunakan adalah regresi linear. Tahapan analisis yang digunakan adalah sebagai berikut:

1. Persamaan Regresi

$$
K L K=\alpha+\mathrm{bPS}+\varepsilon
$$

Keterangan:

$$
\begin{array}{ll}
\text { KLK } & : \text { Kualitas Laporan Keuangan } \\
\mathrm{a} & : \text { Konstanta } \\
\mathrm{b} & : \text { Intersep } \\
\mathrm{PS} & : \text { Penerapan Sistem Informasi Akutansi } \\
\varepsilon & : \text { Nilai error }
\end{array}
$$

2. Statistik Deskriptif

Tahapan ini digunakan untuk melihat nilai mean, standart deviasi, dan nilai maksimal dan minimal. Analisis deskriptif hanya memberikan informasi atau gambaran mengenai data yang dapat digunakan oleh peneliti sebagai dasar penarikan kesimpulan

3. Uji Kualitas Data

\section{a. Uji Reliabilitas}

Uji reliabilitas merupakan alat uji yang digunakan untuk menilai indikator dari suatu variabel yang terdapat pada kuesioner. Dan suatu kuesioner dapat dinilai reliable jika responden menjawab pertanyaan pada kuesioner secara konsisten (Ghozali, 2016). Uji statistik Cronbach Alpha dapat digunakan untuk mengukur tingkat reliabilitas suatu variabel. Suatu variabel dapat dikatakan reliable atau konsisten jika nilai Cronbach Alpha $>0.70$ (Gozhali, 2016).

b. Uji Validitas

Uji validitas merupakan alat uji yang digunakan untuk mengukur atau menilai sah atau tidaknya suatu kuesioner. Suatu kuesioner dapat dikatakan sah jika kuesioner mampu mengungkapkan sesuatu yang akan diukur dengan menggunakan kuesioner tersebut (Ghozali, 2016). Signifikansi Korelasi 
yang dipakai dalam penelitian ini adalah 0,05 . Apabila nilai signifikansinya lebih kecil dari 0,05 maka butir pertanyaan tersebut valid dan apabila nilai signifikansinya lebih besar dari 0,05, maka butir pertanyaan tersebut tidak valid (Gozhali, 2016).

4. Uji Asumsi Klasik

Uji asumsi klasik yang digunakan dalam penelitian ini adalah uji normalitas dan heterokedastisitas

5. Uji Kelayakan Model

Pengujian yang dilakukan pada tahapan ini adalah pengujian statistik $F$ dan uji signifikan parameter individual atau uji $t$.

6. Pengujian Hipotesis

Penilaian hipotesis pada penelitian ini digunakan dengan menggunakan regresi linear. Pengambilan keputusan pada pengujian hipotesis ini berdasarkan pada ketentuan sebagai berikut :

a. Perumusan Hipotesis

H0 : Variabel Independen (Penerapan Sistem Informasi Akuntansi) tidak memiliki pengaruh terhadap variabel Dependen (Kualitas Laporan Keuangan)

H1 : Variabel Independen (Penerapan Sistem Informasi Akuntansi) memiliki pengaruh terhadap variabel Dependen (Kualitas Laporan Keuangan)

b. Pengambilan Kesimpulan,

(1)Apabila nilai regresi > 0,05 maka H0 diterima, dan $\mathrm{H} 1$ ditolak.

(2)Apabila nilai regresi < 0,05 maka H0 ditolak, dan $\mathrm{H} 1$ diterima.

\section{HASIL DAN PEMBAHASAN}

Karakteristik Responden

berikut adalah demografi yang menjelaskan karakteristik responden penelitian ini:
Tabel 2. Demografi Responden

\begin{tabular}{|l|c|c|}
\hline \multicolumn{1}{|c|}{ Profil Responden Berdasarkan Umur } \\
\hline 18 s/d 25 tahun & Jumlah & $\begin{array}{c}\text { Presentase } \\
(\%)\end{array}$ \\
\hline 26 s/d 35 tahun & 66 & 24 \\
\hline 36 s/d 45 tahun & 8 & 68 \\
\hline Total & 97 & 8 \\
\hline
\end{tabular}

Profil Responden Berdasarkan Jenis Kelamin

\begin{tabular}{|l|c|c|}
\hline \multicolumn{1}{|c|}{ Jenis Kelamin } & Jumlah & $\begin{array}{c}\text { Presentase } \\
(\%)\end{array}$ \\
\hline Laki - laki & 55 & 57 \\
\hline Perempuan & 42 & 43 \\
\hline Total & 97 & 100 \\
\hline
\end{tabular}

\begin{tabular}{|l|c|c|}
\hline \multicolumn{2}{|c|}{ Profil Responden Berdasarkan Jabatan } \\
\hline $\begin{array}{l}\text { Bidang Penyusu- } \\
\text { nan APBD }\end{array}$ & Jumlah & $\begin{array}{c}\text { Presentase } \\
(\%)\end{array}$ \\
\hline $\begin{array}{l}\text { Perbendaharaan } \\
\text { dan Akuntansi }\end{array}$ & 45 & 25 \\
\hline $\begin{array}{l}\text { Bidang Pendapa- } \\
\text { tan }\end{array}$ & 28 & 46 \\
\hline Total & 97 & 29 \\
\hline
\end{tabular}

Profil Responden Berdasarkan Lama Bekerja

\begin{tabular}{|c|c|c|}
\hline Lama Bekerja & Jumlah & $\begin{array}{c}\text { Presentase } \\
(\%)\end{array}$ \\
\hline $\begin{array}{l}\leq 1 \text { tahun } \mathrm{s} / \mathrm{d} 5 \\
\text { tahun }\end{array}$ & 67 & 69 \\
\hline $\begin{array}{l}6 \text { tahun s/d } 10 \\
\text { tahun }\end{array}$ & 29 & 30 \\
\hline$\geq 10$ tahun & 1 & 1 \\
\hline Total & 97 & 100 \\
\hline \multicolumn{3}{|c|}{ Profil Responden Berdasarkan Pendidikan } \\
\hline Pendidikan & Jumlah & $\begin{array}{c}\text { Presentase } \\
(\%)\end{array}$ \\
\hline SLTA & 9 & 9 \\
\hline Diploma & 20 & 21 \\
\hline Sarjana (S1) & 67 & 69 \\
\hline Pascasarjana (S2) & 1 & 1 \\
\hline Total & 97 & 100 \\
\hline
\end{tabular}

Hasil pengujian statistik deskriptif dapat dilihat pada tabel berikut ini:

Tabel 3. Hasil Statistik Deskriptif Variabel

\begin{tabular}{|l|c|l|l|l|l|}
\hline Variabel & $\mathrm{N}$ & $\begin{array}{c}\text { Std. } \\
\text { Deviation }\end{array}$ & Mean & Maximum & Minimum \\
\hline KLK & 97 & 0.3865 & 0.4153 & 5.0000 & 3.2000 \\
\hline PS & 97 & 0.3879 & 0.4230 & 5.0000 & 3.3000 \\
\hline
\end{tabular}

Dari jumlah keseluruhan responden yaitu sebanyak 97 orang yang mengisi kuesioner terkait indikator 
penerapan sistem informasi akuntansi memiliki nilai rata-rata sebesar 4.23 yang artinya sebagian besar responden menjawab setuju. Sedangkan untuk indikator kualitas laporan keuangan memiliki rata-rata 4.15 yang artinya sebagian besar responden juga memberikan jawaban setuju. Standar deviasi menunjukkan keragaman sampel yang dipilih oleh peneliti. Penerapan sistem informasi akuntansi memiliki standar deviasi tertinggi yaitu sebesar 0.387 , sedangkan standar deviasi variabel kualitas laporan keuangan sebesar 0.386 .

\section{Analisis Data}

1. Uji Kualitas Data

a. Uji Reliabilitas

Hasil uji statistik Cronbach Alpha variabel Penerapan Sistem Informasi Akuntansi (PS) menunjukkan nilai $0.760 \quad(76 \%)$, sedangkan variabel Kualitas Laporan Keuangan (KLK) menunjukkan nilai 0.740 (74\%). Nilai Cronbach Alpha tiap variabel lebih dari $0.70(70 \%)$ yang artinya variabel pada penelitian ini sudah cukup reliabel. Hasil uji reliabilitas dapat dilihat pada Tabel 4. berikut ini:

Tabel 4. Hasil Uji Reliabilitas

\begin{tabular}{|c|c|c|}
\hline Variabel & $\begin{array}{c}\text { Cronbach } \\
\text { Alpha }\end{array}$ & Keterangan \\
\hline PS & 0.760 & Reliabel \\
\hline KLK & 0.740 & Reliabel \\
\hline
\end{tabular}

\section{b. Uji Validitas}

Hasil uji validitas pada penelitian ini menunjukkan adanya korelasi atau hubungan pada setiap indikator terhadap total nilai variabel dan menghasilkan tingkat signifikansi pada tiap variabel lebih kecil dari $0.05(\alpha=5 \%)$ yang artinya setiap indikator pernyataan adalah valid. Hasil uji validitas dapat dilihat pada Tabel 5 . berikut ini:
Tabel 5. Hasil Uji Validitas

\begin{tabular}{|l|c|c|c|}
\hline Variabel & $\begin{array}{c}\text { Pearson } \\
\text { Corelation }\end{array}$ & Sig. & Keterangan \\
\hline PS & & & \\
\hline PS1 & $0.627^{* *}$ & & \\
PS2 & $0.739^{* *}$ & & \\
PS3 & $0.667^{* *}$ & & \\
PS4 & $0.609^{* *}$ & & \\
PS5 & $0.622^{* *}$ & & \\
PS6 & $0.579^{* *}$ & 0.000 & Valid \\
PS7 & $0.717^{* *}$ & & \\
PS8 & $0.649^{* *}$ & & \\
PS9 & $0.676^{* *}$ & & \\
PS10 & $0.613^{* *}$ & & \\
\hline KLK & $0.636^{* *}$ & & \\
\hline KLK1 & & & \\
KLK2 & $0.770^{* *}$ & & \\
KLK3 & $0.612^{* *}$ & & \\
KLK4 & $0.666^{* *}$ & & \\
KLK5 & $0.590^{* *}$ & & \\
KLK6 & $0.426^{* *}$ & 0.000 & Valid \\
KLK7 & $0.282^{* *}$ & & \\
KLK8 & $0.628^{* *}$ & & \\
KLK9 & $0.640^{* *}$ & & \\
KLK10 & $0.549^{* *}$ & & \\
& $0.636^{* *}$ & & \\
\hline & & & \\
\end{tabular}

2. Uji Asumsi Klasik

Pada penelitian ini menunjukkan hasil uji normalitas dengan menggunakan uji statistik Kolmogorov Smirnoff (K-S) menunjukan nilai signifikansi 0.186 yang artinya lebih besar dari 0.05 (lampiran 7), maka dapat disimpulkan bahwa nilai residual terdistribusi normal. Pada penelitian ini hasil uji heteroskedastisitas dengan menggunkan uji statistik Glesjer menunjukkan tingkat signifikansi diatas 0.05 $(5 \%)$ yaitu 0.315 , artinya pada penelitian ini tidak terjadi heteroskedastisitas

3. Uji Kelayakan Model

Pada penelitian ini hasil uji statistik $F$ menghasilkan nilai $\mathrm{F}$ hitung sebesar 82.355 dengan tingkat signifikansi 0.000 . Oleh karena itu, dapat disimpulkan bahwa Penerapan Sistem Informasi Akuntansi (PS) dapat memprediksi model regresi dan berpengaruh signifikan terhadap variabel terikat yaitu Kualitas Laporan Keuangan (KLK). Dengan ini dapat dinyatakan bahwa model regresi layak digunakan. Hasil uji $\mathrm{t}$ dapat dilihat pada tabel coefficients pada kolom significance, jika nilai signifikansi $\leq 0.05$ 
maka variabel independen berpengaruh signifikan, sebaliknya jika $\geq 0.05$ artinya variabel independen tidak berpengaruh signifikan terhadap variabel dependen. Hasil penujian model regresi linear dapat dilihat pada Tabel 6 berikut ini:

Tabel 6. Analisis Regresi Linier Sederhana

\begin{tabular}{|c|c|c|c|}
\hline Variabel & B & $\mathrm{T}$ & Sig. \\
\hline Konstanta & 1.280 & 4.028 & 0.000 \\
\hline $\begin{array}{l}\text { Penerapan } \quad \text { Sistem } \\
\text { Informasi Akuntansi (PS) }\end{array}$ & 0.679 & 9.075 & 0.000 \\
\hline $\begin{array}{l}\mathrm{R} \\
\text { Adjusted R Square } \\
\text { F hitung } \\
\text { F Sig. }\end{array}$ & \multicolumn{3}{|c|}{$\begin{array}{l}=0.681 \\
=0.459 \\
=82.335 \\
=0.000\end{array}$} \\
\hline
\end{tabular}

Dari hasil analisis regresi linier sederhana pada tabel 1. diatas dapat dirumuskan dengan menggunakan persamaan berikut:

$$
\text { KLK }=1.280+0.679 \mathrm{PS}
$$

Dari persamaan regresi linier sederhana diatas menjelaskan nilai konstanta pada penelitian ini sebesar 1.280. Artinya jika nilai variabel PS tetap, maka nilai variabel KLK sebesar 1.280. Koefisien regresi variabel PS sebesar 0.679 yang artinya setiap kenaikan penerapan sistem informasi akuntansi sebanyak 1 satuan, maka akan menaikkan kualitas laporan keuangan sebesar 1.280. Nilai koefisien regresi pada penelitian ini menunjukkan arah model regresi yang positif.

\section{Pembahasan}

Pada penelitian ini, peneliti ingin melakukan uji pengaruh penerapan sistem informasi akuntansi terhadap kualitas laporan keuangan pada BPKPD kota Surabaya. Hasil analisis data menunjukkan bahwa penerapan sistem informasi akuntansi berpengaruh terhadap kualitas laporan keuangan, maka hipotesis (H1) pada penelitian ini diterima. Hal ini menunjukkan bahwa hasil penelitian ini sejalan dengan penelitian Prasisca, dkk (2012), Juwita (2013), Silviana dan Antoni (2014) yang juga menyatakan bahwa penerapan sistem informasi akuntansi berpengaruh terhadap kualitas laporan keuangan.

BPKPD kota Surabaya merupakan lembaga atau instansi pemerintah yang menerbitkan laporan keuangan sebagai bentuk pertanggung jawaban terhadap pemerintah pusat dan memenuhi kebutuhan informasi yang bermanfaat bagi pihak ang berkepentingan sebagai dasar pengambilan keputusan. Laporan keuangan pemerintah yang dihasilkan akan melalui proses pemerinksaan oleh Badan Pemeriksa Keuangan (BPK), sehinngga laporan keuangan harus disajikan sesuai dengan Standar Akuntansi Pemerintah (SAK). Menurut Peraturan Pemerintah No. 71 Tahun 2010 yang juga didukung oleh Hasanah dan Fauzi (2017:37) menjelaskan mengenai Empat karekteristik yang merupakan prasyarat ukuran normatif yang harus diwujudkan agar dapat memenuhi kualitas laporan keuangan yang diharuskan yaitu relevan, andal, dapat dibandingkan, dan dapat dipahami. Teori kegunaan keputusan informasi menjelaskan bahwa sebagai dasar dari pengambilan keputusan dimulai dengan menyediakan informasi keuangan ang sesuai dengan kondisi suatu perusahaan (Staubus, 2002). Teori kegunaan-keputusan informasi akuntansi dapat dilihat dari nilai manfaat informasi ang disajikan dalam laporan keuangan yang memenuhi standard an komponen pelaporan sebagai dasar pengambilan keputusan (Silviana dan Antoni, 2014). Dari hasil penelitian ini bila dikaitkan dengan teori kegunaan keputusan, dan hasil penelitian terdahulu dapat disimpulkan bahwa dengan memanfaatan sistem informasi akuntansi membantu BPKPD kota Suarabaya dalam memenuhi dan menyediakan informasi yang sesuai sebagai dasar pengambilan keputusan oleh pihak berkepentingan, serta memenuhi tujuan dari pelaporan keuangan pemerintah daerah.

Hasil jawaban responden pada penelitian ini menunjukkan hasil yang mendukung hipotesis pada penelitian ini yaitu penerapan sistem informasi akuntansi berpengaruh terhadap kualitas laporan keuangan pada BPKPD kota Surabaya. BPKPD kota Surabaya menerapkan sistem informasi akuntansi atau aplikasi keuangan berbasis online software dengan nama e-accounting, eaccounting diterapkan sejak tahun 2016 hingga sekarang tahun 2018. Dalam penerapan e-accounting membantu organisasi dalam ketepatan waktu pengumpulan data keuangan dan keakuratan data sehingga proses pengecekan kembali data lebih cepat. Sehingga pada penerapannya e-accounting memberikan pengaruh terhadap kualitas pelaporan keuangan sesuai dengan hasil uji hipotesis pada penelitian ini.

\section{SIMPULAN}

Dari hasil penelitian dan pembahasan mengenai pengaruh penerapan sistem informasi akuntansi terhadap kualitas laporan keuangan dapat disimpulkan bahwa penerapan sistem in- 
formasi akuntansi berpengaruh positif dan signifikan terhadap kualitas pelaporan keuangan pada Badan Pengelola Keuangan dan Pajak Daerah kota Surabaya. Pemanfaatan sistem informasi akuntansi mempengaruhi kualitas informasi yang disajikan BPKPD kota Suarabaya. Dengan memanfaatkan sistem informasi akuntansi sangat membantu dalam pemenuhan dan penyediaan informasi yang bermanfaat sebagai dasar pengambilan keputusan oleh pihak berkepentingan, serta memenuhi tujuan dari pelaporan keuangan pemerintah daerah. Berikut beberapa hal yang menjadi keterbatasan pada penelitian ini:

1. Variabel independen pada penelitian ini masih terbatas, dimana berfokus pada penerapan sistem informasi akuntansi.

2. Keterbatasan akses terhadap jurnal penelitian terdahulu yang mendasari penelitian ini.

3. Peneliti melakukan penelitian pada BPKPD kota Surabaya yang merupakan pusat pengelolaan keuangan daerah kota Surabaya yang menerapkan e-accounting, sedangkan terdapat 72 SKPD yang menerapkan $e$ accounting.

Dari berbagai keterbatasan yang terdapat pada penelitian ini, berikut beberapa saran yang dapat diberikan untuk peneliti selanjutnya yang akan meneliti topik serupa:

1. Perlu adanya penelitian lebih lanjut terkait sistem informasi akuntansi dan mempertimbangkan variabel lain.

2. Disarankan agar peneliti dapat memberikan pendampingan dan penjelasan yang memadai apabila terdapat pernyataan-pernyataan dalam kuesioner yang kurang dipahami oleh responden.

\section{REFERENCES}

Ghozali, I., (2016), Aplikasi Analisis Multivariate dengan Program IBM SPSS 23, Edisi 8, Semarang: Badan Penerbit Universitas Diponegoro.

Halim, A., (2007), Akuntansi Keuangan Daerah, Edisi Ke-3, Jakarta: Salemba Empat.

Hasanah, N., dan Fauzi, A, (2017), Akuntansi Pemerintahan, Bogor: In Media.

Juwita, R., (2013), Pengaruh Implementasi Standar Akuntansi Pemerintahan dan Sistem Informasi Akuntansi Terhadap Kualitas Laporan Keuangan, Jurnal Trikonomika, Vol. 2, No. 2, Desember:201-214.

Peraturan Pemerintah No. 71 Tahun 2010, diakses dari

http://www.djpk.depkeu.go.id/attach/post- pp-no-71-tahun-2010-tentang-standarakuntansi-pemerintahan/PP71.pdf 05/04/18, 21.15.

Prasisca, J., Kharlina, R, dan Yunita, C., (2012), Pengaruh Penerapan Sistem Informasi Akuntansi Keuangan Terhadap Kualitas Laporan Keuangan pada Koperasi Lister PT PLN http://eprint.mdp.ac.id/id/eprint/1478.

Rama, D. V., dan Jones, F. L., (2006), Sistem Informasi Akuntansi, Buku 1, Terjemahan oleh M. Slamet Wibowo, 2008, Jakarta: Salemba Empat. Saputra, B. W., (2015), Pengaruh Implementasi Standar Akuntansi Pemerintahan, Sistem Informasi Akuntansi dan Sistem Pengendalian Internal Terhadap Kualitas Laporan Keuangan Pemerintah Daerah, Jurnal JOM FEKON, Vol. 2, No. 2, Oktober 2015.

Setyowati, L., Isthika, W. dan Pratiwi, R. D., (2016), Faktor - Faktor yang Mempengaruhi Kualitas Laporan Keuangan Pemerintah Daerah Kota Semarang, Jurnal Ekonomi dan Bisnis, Vol. 20, No. 2, 179-191.

Silviana, dan Antoni, E., (2014), Pengaruh Penerapan Sistem Informasi Akuntansi terhadap Kualitas Laporan Keuangan Pemerintah Daerah Jawa Barat, Jurnal Profita, Vol. 6, No. 1, April 2014.

Staubus, G. J., (2000), The Decision-Usefulness Theory of Accounting, New York: Routledge Publishing Inc., diakses dari https://books.google.co.id/books/about/The _Decision_usefulness_Theory_of_Account.htm 1.

Widjajanto, N., (2001), Sistem Informasi Akuntansi, Jakarta: Erlangga.

Yunita, T. A., (2015), Pengaruh Penerapan Standar Akuntansi Pemerintahan, Sistem Pengendalian Internal dan Kompetensi Staf Akuntansi Terhadap Kualitas Laporan Keuangan Pemerintah Daerah, Jurnal JOM FEKON, Vol. 2 No. 2, Oktober 2015. 